\title{
STUDIES ON THE EFFECT OF CLAY AND ORGANIC MATTER CONTENTS ON THE DETERMINATION OF GATION EXCHANGE PROPERTIES IN CLAY SOILS BY THE AMMONIUM ACETATE AND METHYLENE-BLUE METHODS
}

\author{
Raimo Erviö and Osmo Mäkitie \\ Agricultural Research Centre, Department of Soil Science, \\ Tikkurila, Finland
}

Received November 30, 1968

In a previous study it was observed that the so-called methylene-blue adsorption method of PETER and MARKert (1955 and 1961) gave values of cation exchange capacity in Finnish soils comparable to those obtained by the ammonium acetate method (MÄKITIE and ERviö 1966). The correlation coefficient $0.942 * * *$ was at $99.9 \%$ significance level (27 samples of mineral soils). ${ }^{1}$

The studies have been continued in the present work, where results of both methods are compared in a soil sample material of clay soils, particularly with respect to the effect of the mineral and humus content in soil on the values of the total cation exchange capacity and on the mutual ratios between the exchangeable metallic cations.

\section{Experimental}

The soil samples were collected from the Hyvinkää-Nastola area lying on the highest coastal line of the Litorina Sea in South Finland (Hyyppä 1937). The clay material, which is of Glacial origin, contains mostly minerals of mica and weathered materials of illitic type of clay (Salminen 1935, Soveri 1950), as well as of chlorites (Soveri and Hyyprä 1966). These observations have been confirmed in a recent study of topsoil clays of the region of Central-Uusimaa, located somewhat south of the area now investigated (MÄKITIE and VIRRI 1965).

Detailed data of sample material grouped on the basis of decreasing clay content are presented in Table 1. The clay content of the topsoil $(0-20 \mathrm{~cm})$ samples of cultivated soils varies from 21 to 86 per cent. The names of the soil types according to the Finnish

${ }^{1}$ Abbreviations used: $\mathrm{CEC}=$ cation exchange capacity, $\mathrm{MB}=$ methylene-blue, $\mathrm{AA}=$ ammonium acetate. 
Table 1. Analytical data.

\begin{tabular}{|c|c|c|c|c|c|c|c|c|c|}
\hline \multirow[t]{2}{*}{$\begin{array}{c}\text { Sample } \\
\text { No. }\end{array}$} & \multirow[t]{2}{*}{ Soil type } & \multirow{2}{*}{$\begin{array}{l}0^{0} \pi \\
\frac{\pi}{0} V \\
0\end{array}$} & \multirow{2}{*}{ 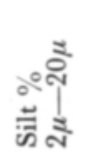 } & \multirow{2}{*}{ 造 } & \multirow{2}{*}{ 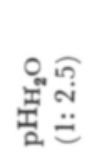 } & \multirow{2}{*}{ 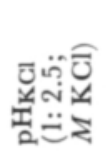 } & \multicolumn{3}{|c|}{$\begin{array}{l}\text { Relative } \\
\text { cations }\end{array}$} \\
\hline & & & & & & & $\mathrm{Ca}^{2+}$ & $\mathrm{Mg}^{2+}$ & $\mathrm{K}^{+}$ \\
\hline a & b & c & d & e & $\mathrm{f}$ & g & $\mathrm{h}$ & $\mathrm{i}$ & j \\
\hline & & & & & & & & & \\
\hline $1 \mathrm{~A}$ & Heavy clay & 86 & 13 & 9.1 & 5.34 & 4.18 & 34.4 & 28.0 & 1.9 \\
\hline $2 n$ & $" n$ & 77 & 12 & 7.0 & 5.26 & 4.10 & 30.4 & 19.2 & 2.3 \\
\hline $3 n$ & $"$ & 74 & 15 & 5.4 & 5.35 & 4.15 & 37.7 & 26.4 & 2.0 \\
\hline $4 n$ & $"$ & 73 & 16 & $\begin{array}{r}5.7 \\
12.9\end{array}$ & 5.34 & 4.21 & 34.5 & 20.3 & 1.3 \\
\hline $5 n$ & $"$ & 72 & 13 & 10.7 & 5.83 & 4.58 & 43.8 & 27.8 & 2.3 \\
\hline $6 n$ & $n$ & 68 & 18 & 4.8 & 5.69 & 4.55 & 43.4 & 30.5 & 2.2 \\
\hline $7 n$ & 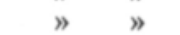 & 67 & 27 & 6.9 & 5.88 & 4.76 & 52.2 & 19.7 & 2.6 \\
\hline $8 n$ & $"$ & 64 & 19 & 8.4 & 5.35 & 4.21 & 34.0 & 16.8 & 2.2 \\
\hline $9 "$ & $"$ & 62 & 26 & 5.5 & 5.68 & 4.44 & 38.2 & 30.3 & 2.3 \\
\hline $10 "$ & $"$ & 62 & 20 & 5.3 & 5.87 & 4.72 & 45.8 & 25.1 & 1.8 \\
\hline $11 \mathrm{~B}$ & Silty clay & 59 & 36 & 10.6 & 5.48 & 4.25 & 34.8 & 13.7 & 1.5 \\
\hline $12 n$ & " & 57 & 35 & 4.8 & 5.68 & 4.51 & 45.9 & 16.7 & 2.9 \\
\hline $13 n$ & $n$ & 53 & 35 & 5.7 & 5.57 & 4.37 & 41.4 & 16.8 & 2.5 \\
\hline $14 »$ & $"$ & 53 & 31 & 5.2 & 5.27 & 3.98 & 32.2 & 15.7 & 2.2 \\
\hline $15 n$ & $"$ & 52 & 20 & 6.9 & 5.62 & 4.51 & 48.7 & 10.6 & 3.2 \\
\hline $16 "$ & $"$ & 51 & 45 & 10.5 & 5.62 & 4.55 & 43.5 & 15.0 & 1.1 \\
\hline $17 n$ & $m$ & 49 & 43 & 6.5 & 5.89 & 4.69 & 48.1 & 19.5 & 1.8 \\
\hline $18 n$ & $"$ & 47 & 35 & 6.1 & 5.42 & 4.24 & 37.0 & 13.3 & 2.7 \\
\hline $19 "$ & $"$ & 47 & 36 & 5.4 & 5.54 & 4.25 & 35.8 & 25.4 & 1.9 \\
\hline $20 "$ & $"$ & 46 & 39 & 9.7 & 5.80 & 4.73 & 53.1 & 11.0 & 0.4 \\
\hline $21 "$ & $"$ & 46 & 38 & 6.9 & 5.55 & 4.40 & 36.4 & 18.2 & 1.9 \\
\hline $22 "$ & $"$ & 46 & 41 & 5.2 & 5.47 & 4.17 & 39.6 & 15.7 & 1.4 \\
\hline $23 n$ & Sandy clay & 46 & 16 & 10.7 & 5.68 & 4.63 & 46.9 & 16.8 & 1.4 \\
\hline $24 n$ & Clayey silt & 43 & 51 & 12.3 & 5.48 & 4.42 & 42.9 & 78 & 1.9 \\
\hline $25 n$ & Silty clay & 43 & 32 & 8.4 & 5.47 & 4.38 & 43.8 & 17.2 & 1.9 \\
\hline $26 n$ & Sandy clay & 43 & 20 & 6.0 & 5.81 & 4.69 & 47.8 & 17.1 & 1.9 \\
\hline $27 n$ & Clayey silt & 40 & 50 & 8.2 & 5.51 & 4.38 & 38.4 & 14.4 & 2.6 \\
\hline $28 n$ & Sandy clay & 40 & 31 & 6.2 & 5.64 & 4.43 & 39.6 & 12.1 & 2.3 \\
\hline $29 \mathrm{C}$ & $»$ & 39 & 25 & 11.0 & 6.22 & 5.34 & 63.8 & 7.6 & 2.4 \\
\hline $30 "$ & 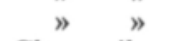 & 38 & 23 & 7.9 & 5.52 & 4.45 & 38.8 & 23.6 & 1.2 \\
\hline $31 n$ & Clayey silt & 35 & 50 & 11.6 & 5.88 & 4.90 & 60.1 & 8.5 & 1.1 \\
\hline $32 "$ & Sandy clay & 34 & 37 & 3.3 & 5.53 & 4.31 & 35.4 & 17.8 & 3.2 \\
\hline $33 n$ & $m \quad "$ & 33 & 31 & 8.7 & 5.83 & 4.73 & 51.0 & 7.1 & 3.4 \\
\hline $34 n$ & $n$ & 32 & 41 & 10.3 & 5.39 & 4.37 & 40.1 & 10.1 & 1.5 \\
\hline $35 »$ & $"$ & 32 & 54 & 7.9 & 5.07 & 3.97 & 19.2 & 11.8 & 2.5 \\
\hline $36 »$ & Clayey silt & 32 & 56 & 5.7 & 5.73 & 4.66 & 41.5 & 11.5 & 4.2 \\
\hline $37 n$ & Sandy clay & 32 & 45 & 3.6 & 5.31 & 3.94 & 33.7 & 13.9 & 1.9 \\
\hline $38 n$ & $"$ & 31 & 34 & 5.6 & 5.57 & 4.26 & 35.8 & 10.2 & 2.4 \\
\hline $39 »$ & Clayey silt & 30 & 56 & 7.9 & 5.55 & 4.53 & 42.4 & 13.3 & 2.0 \\
\hline $40 "$ & Sandy clay & 30 & 41 & 7.0 & 5.24 & 4.12 & 30.3 & 7.5 & 1.1 \\
\hline $41 \%$ & " & 30 & 45 & 4.7 & 5.91 & 4.92 & 54.1 & 9.5 & 2.5 \\
\hline $42 "$ & Silt & 27 & 58 & 3.9 & 6.81 & 5.52 & 66.7 & 23.8 & 1.0 \\
\hline $43 n$ & Silty loam & 26 & 47 & 9.8 & 5.32 & 4.18 & 30.8 & 7.7 & 1.2 \\
\hline $44 n$ & Sandy loam & 22 & 40 & 4.1 & 5.65 & 4.40 & 39.7 & 14.8 & 1.3 \\
\hline $45 "$ & Sandy silt & 21 & 54 & 9.4 & 6.03 & 5.12 & 61.6 & 7.8 & 1.3 \\
\hline $\begin{array}{r}\text { Group } \\
\text { mea }\end{array}$ & values & 71 & 18 & 7.6 & 5.56 & 4.39 & 39.4 & 24.4 & 2.1 \\
\hline Group & & & & & & & & & \\
\hline mea & values & 48 & 35 & 7.5 & 5.58 & 4.42 & 42.0 & 15.4 & 2.0 \\
\hline Group & & & & & & & & & \\
\hline meat & values & 31 & 43 & 7.2 & 5.68 & 4.57 & 43.8 & 12.1 & 1.2 \\
\hline
\end{tabular}




\begin{tabular}{|c|c|c|c|c|c|c|c|c|c|c|}
\hline \multirow{2}{*}{\multicolumn{2}{|c|}{$\begin{array}{l}\text { distribution of } \\
\text { in CEC \% }\end{array}$}} & \multirow{3}{*}{ ن } & \multirow{3}{*}{ 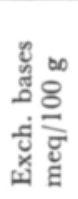 } & \multirow{3}{*}{ อ゚ } & \multirow{3}{*}{ 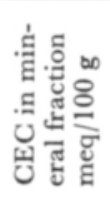 } & \multirow{3}{*}{ 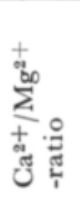 } & \multicolumn{4}{|c|}{$\begin{array}{l}\text { Methylene-blue method } \\
\text { CEC }\end{array}$} \\
\hline & & & & & & & \multirow{2}{*}{ 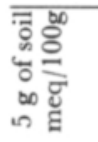 } & \multirow{3}{*}{$\begin{array}{c}\text { Extr. } \\
\text { pH } \\
\\
\text { s }\end{array}$} & \multirow{3}{*}{ 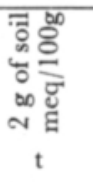 } & \multirow{3}{*}{$\begin{array}{c}\text { Extr. } \\
\text { pH } \\
\\
\quad \mathrm{u}\end{array}$} \\
\hline $\mathrm{Na}^{+}$ & $\mathrm{H}^{+}$ & & & & & & & & & \\
\hline k & 1 & $\mathrm{~m}$ & $\mathrm{n}$ & o & $\mathrm{p}$ & $q$ & $\mathbf{r}$ & & & \\
\hline 0.9 & 34.8 & 37.8 & 24.7 & 65 & 33.3 & 1.23 & 12.5 & 6.4 & 24.3 & 6.4 \\
\hline 0.6 & 47.5 & 32.0 & 16.8 & 52 & 27.6 & 1.58 & 12.3 & 6.3 & 18.6 & 6.6 \\
\hline 1.3 & 32.6 & 29.9 & 20.2 & 68 & 23.9 & 1.43 & 11.9 & 6.4 & 22.5 & 6.4 \\
\hline 1.1 & 42.8 & 32.2 & 18.4 & 57 & 27.8 & 1.70 & 12.4 & 6.5 & 23.0 & 6.5 \\
\hline 0.6 & 25.5 & 34.0 & 25.3 & 74 & 28.6 & 1.58 & 12.3 & 6.5 & 22.0 & 6.6 \\
\hline 0.4 & 23.5 & 29.8 & 22.8 & 77 & 20.0 & 1.42 & 12.1 & 6.5 & 20.2 & 6.5 \\
\hline 0.9 & 24.6 & 38.0 & 28.6 & 75 & 25.9 & 2.65 & 12.2 & 6.5 & 19.9 & 6.5 \\
\hline 0.6 & 46.4 & 31.0 & 16.6 & 54 & 23.6 & 2.02 & 12.1 & 6.5 & 21.1 & 6.6 \\
\hline 0.8 & 28.4 & 28.4 & 20.3 & 71 & 22.9 & 1.26 & 11.8 & 6.5 & 19.6 & 6.6 \\
\hline 0.8 & 26.5 & 28.7 & 21.1 & 74 & 22.5 & 1.82 & 11.8 & 6.4 & 21.4 & 6.6 \\
\hline 0.7 & 49.3 & 31.7 & 16.1 & 51 & 21.8 & 2.54 & 11.9 & 6.6 & 21.3 & 6.6 \\
\hline 0.6 & 33.9 & 25.1 & 16.6 & 66 & 16.0 & 2.75 & 12.0 & 6.6 & 17.6 & 6.5 \\
\hline 0.7 & 38.6 & 23.7 & 14.6 & 62 & 14.9 & 2.46 & 11.4 & 6.5 & 19.6 & 6.4 \\
\hline 0.7 & 49.1 & 22.9 & 11.6 & 51 & 17.4 & 2.06 & 11.5 & 6.4 & 18.5 & 6.5 \\
\hline 0.4 & 37.1 & 27.2 & 17.1 & 63 & 18.6 & 4.59 & 11.8 & 6.4 & 19.8 & 6.5 \\
\hline 0.8 & 39.6 & 32.3 & 19.5 & 60 & 19.9 & 2.90 & 11.9 & 6.2 & 21.6 & 6.5 \\
\hline 0.5 & 30.1 & 29.1 & 20.3 & 70 & 14.0 & 2.47 & 11.9 & 6.5 & 21.4 & 6.4 \\
\hline 0.6 & 46.4 & 24.8 & 13.3 & 54 & 17.4 & 2.78 & 11.8 & 6.4 & 20.8 & 6.6 \\
\hline 0.4 & 36.5 & 23.6 & 15.0 & 64 & 13.4 & 1.41 & 11.1 & 6.4 & 18.5 & 6.4 \\
\hline 0.4 & 35.1 & 26.8 & 17.4 & 65 & 19.2 & 4.83 & 11.1 & 6.5 & 20.4 & 6.5 \\
\hline 0.4 & 43.1 & 25.1 & 14.3 & 57 & 15.6 & 2.00 & 11.8 & 6.4 & 20.0 & 6.5 \\
\hline 0.6 & 42.7 & 25.4 & 14.6 & 57 & 12.6 & 2.52 & 11.3 & 6.4 & 17.5 & 6.6 \\
\hline 0.5 & 34.4 & 32.6 & 21.4 & 66 & 16.5 & 2.79 & 12.0 & 6.4 & 23.3 & 6.5 \\
\hline 04 & 47.0 & 32.3 & 17.1 & 53 & 17.2 & 5.50 & 12.2 & 6.3 & 21.9 & 6.5 \\
\hline 0.5 & 36.6 & 26.0 & 16.5 & 63 & 14.6 & 2.55 & 11.9 & 6.4 & 20.3 & 6.5 \\
\hline 0.7 & 32.5 & 25.9 & 17.5 & 68 & 16.3 & 2.80 & 11.6 & 6.5 & 19.2 & 6.4 \\
\hline 0.9 & 43.7 & 21.6 & 12.2 & 56 & 13.1 & 2.67 & 11.8 & 6.4 & 18.5 & 6.5 \\
\hline 0.5 & 45.5 & 21.9 & 11.9 & 54 & 14.5 & 3.27 & 11.3 & 6.5 & 14.7 & 6.4 \\
\hline 0.7 & 25.5 & 29.4 & 21.9 & 74 & 14.4 & 8.39 & 12.1 & 6.5 & 21.4 & 6.5 \\
\hline 0.6 & 35.8 & 24.7 & 15.8 & 64 & 15.5 & 1.64 & 12.0 & 6.4 & 22.0 & 6.6 \\
\hline 0.7 & 29.6 & 31.5 & 22.2 & 70 & 14.0 & 7.07 & 12.1 & 6.4 & 21.9 & 6.5 \\
\hline 0.5 & 43.1 & 16.6 & 9.4 & 57 & 10.4 & 1.99 & 9.6 & 6.5 & 14.3 & 6.6 \\
\hline 0.5 & 38.0 & 22.3 & 13.8 & 62 & 11.1 & 7.18 & 11.6 & 6.5 & 19.4 & 6.6 \\
\hline 0.6 & 47.7 & 22.4 & 11.7 & 52 & 11.5 & 3.97 & 11.8 & 6.3 & 20.8 & 6.5 \\
\hline 0.7 & 65.8 & 22.8 & 7.8 & 34 & 10.8 & 1.63 & 10.8 & 6.3 & 18.0 & 6.4 \\
\hline 0.9 & 41.9 & 19.1 & 11.1 & 58 & 8.2 & 3.61 & 10.3 & 6.4 & 15.0 & 6.4 \\
\hline 1.2 & 49.3 & 15.2 & 7.7 & 51 & 10.6 & 2.42 & 9.5 & 6.5 & 13.6 & 6.5 \\
\hline 0.7 & 50.9 & 20.8 & 10.2 & 49 & 11.2 & 3.51 & 10.6 & 6.5 & 16.0 & 6.4 \\
\hline 0.7 & 41.6 & 21.9 & 12.8 & 58 & 11.2 & 3.19 & 10.9 & 6.4 & 17.7 & 6.4 \\
\hline 0.4 & 60.7 & 22.5 & 8.8 & 39 & 10.2 & 4.04 & 10.9 & 6.4 & 18.9 & 6.6 \\
\hline 0.5 & 33.4 & 19.9 & 13.2 & 66 & 11.9 & 7.21 & 10.7 & 6.6 & 15.4 & 6.4 \\
\hline 1.3 & 7.2 & 20.7 & 19.2 & 93 & 9.9 & 2.80 & 11.3 & 6.6 & 17.7 & 6.6 \\
\hline 0.9 & 59.4 & 18.9 & 7.7 & 41 & 8.7 & 4.00 & 11.2 & 6.3 & 17.6 & 6.7 \\
\hline 1.0 & 43.2 & 15.0 & 8.5 & 57 & 7.5 & 2.68 & 9.1 & 6.4 & 12.0 & 6.5 \\
\hline 0.5 & 28.8 & 24.9 & 17.7 & 71 & 8.3 & 7.90 & 12.0 & 6.5 & 20.4 & 6.4 \\
\hline 0.8 & 33.3 & 32.2 & 21.5 & 66.7 & 25.6 & 1.61 & 11.94 & 6.45 & 21.24 & 6.52 \\
\hline 0.6 & 40.1 & 26.6 & 15.9 & 60.0 & 16.2 & 2.73 & 11.66 & 6.42 & 19.72 & 6.47 \\
\hline 0.7 & 41.4 & 21.7 & 12.9 & 58.6 & 10.9 & 3.61 & 10.97 & 6.44 & 17.76 & 6.49 \\
\hline
\end{tabular}


classification are given in column $\mathrm{b}$. The organic matter content varies from 3.3 to 12.9 per cent and the pH-values from 5.1 to 6.8 in soil: water $(1: 2.5)$ suspension. The samples were pre-treated by air-drying, sieved through a $2-\mathrm{mm}$ round-holed sieve and homogenized.

M e t h od s. The methylene-blue adsorption method used was principally the same as reported previously (Peter and Markert 1955, Mäkitie and Erviö 1966). Two subsamples, two and five grams, were weighed and separately treated with $50 \mathrm{ml}$ of aqueous $0.4 \%$ methylene-blue solution ("Methylenblau B»/E. Merck AG).

The ammonium acetate method has also been described in detail previously. A molar ammonium acetate solution ( $\mathrm{pH}$ adjusted to 7 ) was used as an extractant for repeated extractions of the cations (Schollenberger and Simon 1945, Mäkitie and Virri 1965). The total cation exchange capacity was determined by exchanging the ammonium ions with $M$ potassium chloride solution, and the liberated ammonium ions were analyzed by Kjeldahl-distillation.

Hydrogen peroxide $(30 \%$ ) was used for oxidizing the organic matter in soil samples where the CEC of pure mineral matter was to be determined.

The absorption was measured with a Beckman Model DU spectrophotometer with 10 -mm cells at a wavelength of 510 millimicrons (slit width $0.055 \mathrm{~mm}$ ).

The particle size distribution analysis was carried out by the sieving and pipette method, where organic matter was eliminated by the hydrogen peroxide treatment and sodium pyrophosphate was used as a dispersing agent.

The $\mathrm{pH}$ determinations were carried out by means of a Radiometer PHM 4c potentiometer with a glass electrode.

The determinations of the exchangeable hydrogen and of the organic matter content were carried out by the same methods as previously (MÄKITIE and ERVIÖ 1966).

\section{CEC as determined by the methylene-blue method}

The CEC was determined in two ways, i.e. two and five grams of soil were taken for measuring the adsorption of the dye. The concentration of the MB-solution, the dilution and the wavelength for absorptivity measurement were the same for both amounts of soil. Compared with the AA-method, the values obtained with two grams of soil by the MBmethod gave somewhat better correlation $\left(\mathrm{r}=0.86^{* * *}\right)$ than those with five grams (MB-method) $(\mathrm{r}=0.84 * * *)$. The best correlation $\left(\mathrm{r}=0.88^{* * *}\right)$ exists between the two MB-methods. The differences, however, are not statistically significant. The average ratio between the CEC-values (meq/100 g) obtained by the MB-method with two grams and five grams of soil was 1.7 to 1.0. The increasing adsorption with the wider extracting ratio is due to a more complete exposure of the surface of soil particles, a phenomenon observed before as a natural result of more effective exchange when the concentration of the exchanging cation is increased. The process of exchange is incomplete in the case of the five gram samples while with the two gram samples the CEC-values approach those obtained by the AA-method. The relative values obtained by these three methods are $0.4-0.7-1.0$.

By the MB-method the increase in the fineness of the soil and humus content also increases the dye adsorption. Results of experiments with five soils and ten soil-dye ratios are shown in Fig. 1. 


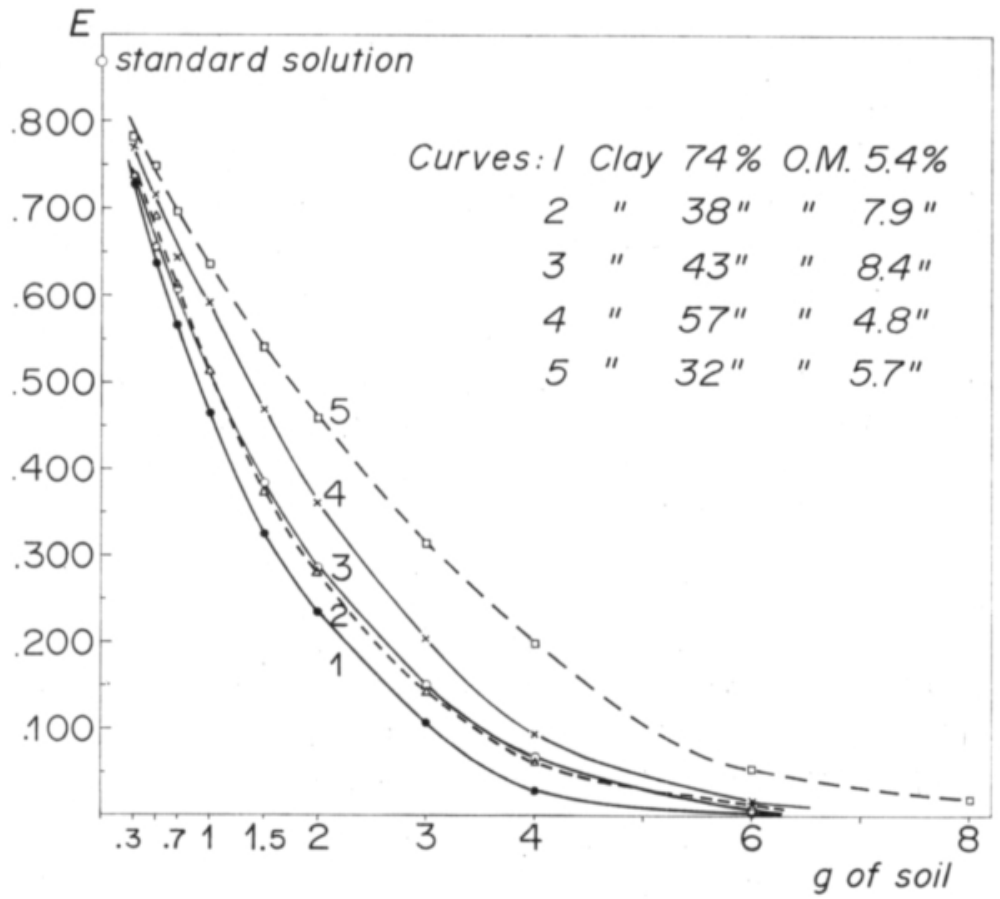

Fig. 1. Absorbance of dyed soil solution (MB-method) as a function of soil-dye ratio in five soils with varying clay and humus contents.

In spite of the parallel shape of the curves, the relative dye-adsorption of different soils varies considerably with the soil-dye ratio. In coarser soils (e.g.curve 5) the effect of the soil-dye ratio is relatively low as indicated by the more linear shape of the curve. With increasing clay and humus contents (e.g. curves 3 and 4 ) the adsorption becomes more dependent on the soil-dye ratio. The effect of humus is relatively more pronounced than that of clay as indicated by a comparison of curves 2 and 3 to curve 4 . It is apparent that when extracting with $50 \mathrm{ml}$ of 0.4 per cent MB-solution no more than 3-4 grams of soil should be used.

The $\mathrm{pH}$-value 6.80 of the buffered MB-solution decreases during the extraction generally to $6.2-6.6$ (MB $5 \mathrm{~g}$ ) and to $6.4-6.7$ (MB $2 \mathrm{~g}$ ).

\section{The effect of the clay fraction}

The CEC of normal soil is mostly due to the clay fraction, particularly to the colloidal clay fraction (Whitt and Baver 1937, Hallsworth and Wilkinson 1958). Silt also increases the CEC to some extent (RENGER 1965), although in our soils its effect is relatively insignificant (HEINONEN 1960).

The CEC-values are in a highly significant correlation to the clay content of the soils under study (see below). The best correlation $\left(\mathrm{r}=0.79^{* * *}\right)$ obtained by the AA-method is significantly higher (at $95 \%$ signif. level) than the lowest $(\mathrm{r}=0.56)$ obtained by the MB-method. 
The CEC-values were determined also by the AA-method after a hydrogen peroxide treatment in order to eliminate the effect of organic material (Table 1, p). A very clear correlation $\left(\mathrm{r}=0.95^{* * *}\right)$ was now obtained between the CEC of the mineral fraction and the clay content of soil. It seems that the whole obtainable capacity is due to the clay in the mineral fraction only (the fraction attributable to regression, 91 per cent). This result confirms the observation of HeINONEN (1960) regarding to the insignificance of silt. According to Pratt (1957) about $15 \%$ of the total content of organic material cannot be eliminated by the hydrogen peroxide treatment. This effect must be taken into account in addition to the possible effect of the silt fraction. If we suppose the whole CEC of the mineral fraction to be due to the clay fraction, the mean CEC of the clay fraction in our population is $30.2 \mathrm{meq} / 100 \mathrm{~g}$ clay, and the range of variation $22.7-36.3 \mathrm{meq} / 100 \mathrm{~g}$.

\section{The effect of the organic matter}

Soil organic matter causes a considerable increase in the CEC as shown by several investigators (Hissink 1926, Mrtchell 1932, Williams 1932, Yuan et al. 1967, etc.). The effect of organic matter on the CEC, in contrast to that of clay, is more evident if the CEC is determined by the MB-method than by the AA-method.

\begin{tabular}{|c|c|c|}
\hline \multicolumn{2}{|c|}{$\begin{array}{c}\text { Method for } \\
\text { CEC determination }\end{array}$} & \multirow{2}{*}{$\begin{array}{c}\begin{array}{c}\text { Correlation } \\
\text { coefficient }\end{array} \\
0.79 * * *\end{array}$} \\
\hline / clay & / clay content & \\
\hline $\mathrm{MB}(2 \mathrm{~g}) / "$ & $"$ & $0.56 * * *$ \\
\hline MB $(5 \mathrm{~g}) / "$ & " & $0.63 * * *$ \\
\hline \multicolumn{2}{|c|}{ AA / humus content } & $0.54 * * *$ \\
\hline $\mathrm{MB}(2 \mathrm{~g}) / "$ & $"$ & $0.66 * * *$ \\
\hline MB $(5 \mathrm{~g}) / "$ & $"$ & $0.58 * * *$ \\
\hline
\end{tabular}

The best correlation $\left(\mathrm{r}=0.66^{* * *}\right)$ between the CEC and the humus content was obtained when the CEC was determined by the MB-method using $2 \mathrm{~g}$ samples. The MBmethod with $5 \mathrm{~g}$ samples gave a somewhat lower correlation $\left(\mathrm{r}=0.58^{* * *}\right)$ and the AAmethod $\left(\mathrm{r}=0.54^{* * *}\right)$ a significantly lower one $\left(\mathrm{t}=2.81^{* *}\right)$ than the method first mentioned.

\section{The effect of different cations on the CEC}

On an average 41.7 per cent of the CEC is due to exchangeable c a l c i u m which proportion is somewhat higher than the average in finer soils (group A, Table 1, h) and slightly lower than in coarser soils (group C). However, the variation in the calcium percentage is relatively small and only in seven cases there is a deviation exceeding 10 units of percentage from the mean.

$\mathrm{M}$ a g n e si u m in the exchange complex varies to a much greater extent than calcium (Table 1, i). The values of exchangeable magnesium vary from 7.1 to 30.5 per 
cent, the average being 17.3. The amount of exchangeable magnesium clearly decreases with a decreasing clay content so that in group $\mathrm{A}$ it is $24.4 \%$ and in group $\mathrm{C}$ only $12.1 \%$.

The ratio between the calcium and magnesium ions depends clearly on the clay fraction (Fig. 2 and Table 1, q). The values 1.6, 2.7 and 3.6 were obtained for the ratio $\mathrm{Ca}: \mathrm{Mg}$ in groups $\mathrm{A}, \mathrm{B}$ and $\mathrm{C}$, respectively. The correlation between this ratio and the clay percentage is statistically significant $\left(\mathrm{r}=0.56^{* * *}\right)$.

In the population in Fig. 2 eight samples of an exceptionally high $\mathrm{Ca}: \mathrm{Mg}$ ratio can be distinguished. These apparently represent soils with heavy liming and without magnesium fertilizing and with a relatively low content of natural magnesium.

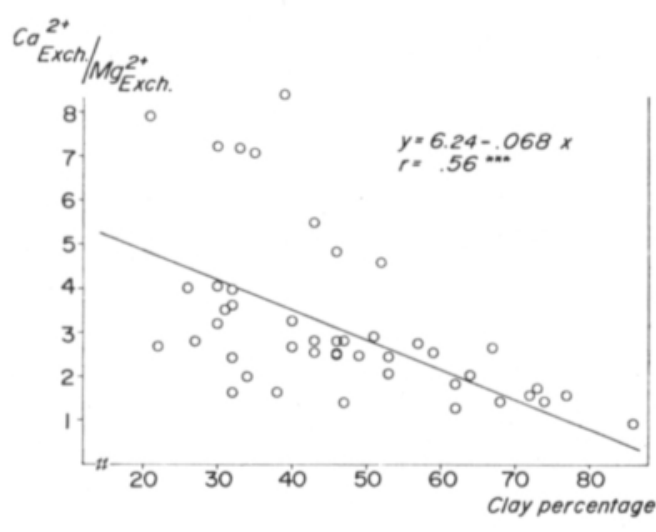

Fig. 2. Correlation between $\mathrm{Ca}^{2+} / \mathrm{Mg}^{2+}$ ratio and clay content of soils.

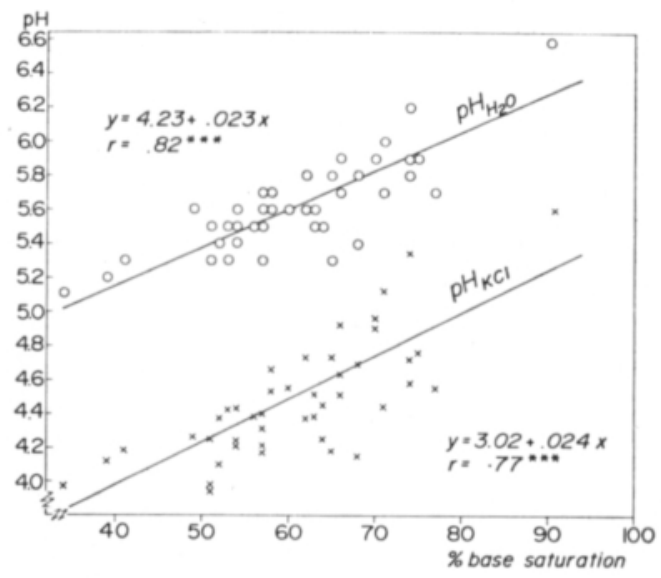

Fig. 3. Correlation between the $\mathrm{pH}$ of soil suspension and base saturation percentage.

The Ca: $\mathrm{Mg}$ ratios obtained are in agreement with those of earlier investigations of Finnish soils. For example, the ratio calculated from the data of AARnio (1942) was 1.68 for heavy clays (18 samples) and 2.91 for sandy clays ( 24 samples). The corresponding ratios calculated from Hernonen's (1956) data were 2.20 for heavy clays ( 5 samples) and 3.28 for silty and sandy clays (8 samples). The increasing role of $\mathrm{Mg}$ in the exchange complex with a decreasing particle size is apparently due to the relatively high $\mathrm{Mg}$-content of clay minerals in Finnish clays. This is also supported by the results of KaILA and Ryti (1968).

Potassium and sodium play a minor part in the exchange complex of Finnish soils (Table 1, j and k) making only $2.4(1.7+0.7)$ per cent of the CEC on an average. The variation range for $\mathrm{K}$ is $0.4-4.2$ and for $\mathrm{Na} 0.4-1.3$ per cent. The percentage of exchangeable $\mathrm{K}$ decreases with a decreasing clay content and is lowest in group $\mathrm{C}$, while no clear effect of clay on sodium can be noticed. Regarding to exchangeable $\mathrm{Mg}, \mathrm{K}$ and $\mathrm{Na}$, the values of Martilla (1965) obtained by the same method are in agreement with the present results while her values for $\mathrm{Ca}$ are somewhat higher.

Ex c h a n g a b l e hy d r o g e n covers on an average $40 \%$ of the cation exchange capacity. In group A, where the clay content is high, the hydrogen percentage is the lowest 
(mean value $33 \%$ ). It is exceptionally low in sample No 42 due to the high $\mathrm{Ca}$ and $\mathrm{Mg}$ contents. The average base saturation percentage is 67 , varying from 34 to 93 . A positive correlation between the saturation percentage and the $\mathrm{pH}$ of soil suspension was obtained, $\mathrm{r}=0.82 * * *\left(\mathrm{pH}_{\mathrm{H}_{2} \mathrm{O}}\right)$ and $\mathrm{r}=0.77 * * *\left(\mathrm{pH}_{M \mathrm{KCl}}\right)$ as shown in Fig. 3 .

\section{$S u m$ mary}

The correlation between CEC-values obtained by ammonium acetate and methyleneblue adsorption methods is relatively good $\left(\mathrm{r}=0.86^{* * *}\right)$. The latter method gives, however, about 30 per cent lower values for exchangeable cations.

The extraction ratio used in the dye adsorption method has a clear effect on the level of the CEC-values. More complete adsorption was obtained with wider ratios. With increasing clay and humus contents the adsorption becomes more dependent on the soildye ratio. The effect of humus is more pronounced than that of clay.

The CEC-values obtained by the ammonium acetate method were in better correlation to the clay content of soils than the values obtained by the dye-adsorption method, while the latter values were better correlated to the organic matter content of the soil.

The percentages of exchangeable potassium, sodium and, especially, of magnesium, decrease when the clay content decreases, while that of calcium increases slightly.

The ratio between exchangeable calcium and magnesium depends on the clay content of the soil $\left(\mathrm{r}=0.56^{* * *}\right)$ so that the value of the ratio $\mathrm{Ca}: \mathrm{Mg}$ increases when the clay content decreases (Table 1, q).

\section{REFERENCES}

Aarnio, B. 1942. Über die Tone Finnlands und ihre Eigenschaften II. Die austauschbaren Basen. Agrogeol. Publ. 53: 1-24.

Hallsworth, E. G. \& Wilkinson, G. K. 1958. The contribution of clay and organic matter to the cation exchange capacity of the soil. J. Agr. Sci. 51: 1-3.

Hernonen, R. 1956. Magnesiumin tarpeesta Suomen pelloissa. Summary: Magnesium requirements in Finnish agriculture. Agrogeol. Publ. 65: 1-32.

- - 1960. Über die Umtauschkapazität des Bodens und verschiedener Bodenbestandteile in Finnland. Z. Pfl.ernähr. Düng. Bodenkunde 88: 49-59.

Hissink, D. J. 1926. The relation between the values $\mathrm{pH}, \mathrm{V}$ and $\mathrm{S}$ (humus) of some humus soils. $\mathrm{S}$ (humus) and $\mathrm{V}$ of these soils with $\mathrm{pH}=7$. The equivalent weight of the humussubstance. Transac. of $2 \mathrm{nd}$ Comm. Int. Soc. Soil Sci. Groningen. Vol. A: 198-206.

HYYPPÄ, E. 1937. Post-glacial changes of shore-line in South-Finland. Bull. Comm. Geol. Finlande N:o 120: $1-225$.

Kaila, A. \& Rytr, R. 1968. Calcium, magnesium and potassium in clay, silt and fine sand fractions of some Finnish soils. J. Sci. Agr. Soc. Finland 40: 1-13.

MArtrila, U. 1965. Exchangeable cations in Finnish soils. Ibid. 37: 148-161.

Mrtchell, J. 1932. The origin, nature and importance of soil organic constituents having base- exchange properties. J. Amer. Soc. Agr. 24: 256-275.

MÄкrтIE, O. \& ERvıö, R. 1966. Comparative studies on the cation exchange properties of mineral soils by the methylene-blue adsorption method and by the ammonium acetate method. Ann. Agric. Fenn. 5: 260-266.

-- - \& VIRRI, K. 1965. On the exchange characteristics of some clay soils in the Middle Uusimaa. Ibid. 4: $277-289$. 
Peter, H. \& Markert, S. 1955. Eine Schnellmethode zur Bestimmung der Sorptionseigenschaften von Ackerböden. Z. landwirtsch. Versuchs- u. Untersuchungswes. 1: 582-596.

- - - - 1961. Die Bestimmung der MB-Sorption mit gepufferter Methylenblaulösung zur Ausschaltung des pH-Einflusses auf die Höhe der Sorptionwerte. Ibid. 7: 426-441.

Pratt, P. F. 1957. Effect of fertilizers and organic materials on the cation-exchange capacity of an irrigated soil. Soil Sci. 83: 85-89.

Renger, M. 1965. Berechnung der Austauschkapazität der organischen und anorganischen Anteile der Böden. Z. Pfl.ernähr. Düng. Bodenkunde 110: 10-26.

SAlminen, A. 1935. On the weathering of rocks and the composition of clays. Selostus: Kallioiden rapautumisesta ja savien kokoomuksesta. Agrogeol. Julk. 40: 1-174.

Schollenberger, C. J. \& Simon, R. H. 1945. Determination of exchangeable bases in soil - ammonium acetate method. Soil Sci. 59: 13-24.

Soveri, U. 1950. Differential thermal analyses of some quaternary clays of Fennoscandia. 103 p. Helsinki.

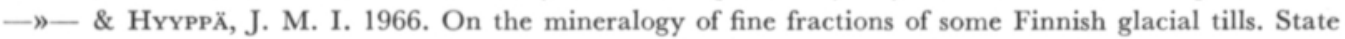
Inst. Techn. Res. Finland, Publ. 113.

Whitt, D. M. \& Baver, L. D. 1937. Particle size in relation to base exchange capacity and hydration properties of Putnam clay. J. Amer. Soc. Agr. 29: 905-916.

Williams, R. 1932. The contribution of clay and organic matter to the base exchange capacity of soils. J. Agr. Sci. 22: 845-851.

Yuan, T. L., Cammon, N. \& Leighty, R. G. 1967. Relative contribution of organic and clay fractions to cation-exchange capacity of sandy soils from several soil groups. Soil Sci. 104: 123-128.

\title{
SELOSTUS:
}

\section{SAVIAINEKSEN JA HUMUKSEN VAIKUTUKSESTA SAVIMAAN KATIONINVAIHTOKAPASITEETIN MÄÄRITTÄMISESSÄ NS. AMMONIUMASETAATTI- JA METYLEENISINIMENETELMILLÄ}

\author{
Raimo Erviö ja Osmo MÄ́rтte
}

Maatalouden tutkimuskeskus, Maantutkimuslaitos, Tikkurila

Tutkimuksessa käsitellyt maat ovat glasiaalisavia pohjoiselta Uudeltamaalta. Kaikki näytteet ovat muokkauskerroksesta. Maista on analysoitu kationinvaihtokapasiteetti ns. ammoniumasetaatti- ja metyleenisinimenetelmillä sekä eri kationien vaihtuvat määrät. Metyleenisinimenetelmä perustuu väri-kationin adsorpoitumiseen maahiukkasten pintaan.

Ammoniumasetaatti- ja metyleenisinimenetelmän antamat kationinvaihtokapasiteettiarvot ovat varsin hyvässä korrelaatiossa keskenään $\left(\mathrm{r}=0.86^{* * *}\right)$, joskin saadut milliekvivalenttimäärät $100 \mathrm{~g}$ maata kohti ovat eri tasoa arvojen keskinäisen suhteen ollessa noin 1: 0.7 .

Metyleenisinimenetelmässä huiskutuksessa käytetty sopiva maamäärä, ts. huiskutusväljyys, vaikuttaa kuitenkin ratkaisevasti saatuun vaihtuvien kationien meq-määrään ollen sitä merkityksellisempi, mitä enemmän savi- ja humusfraktiota maanäyte sisältää.

Ammoniumasetaattimenetelmällä saadut CEC-arvot korreloivat hiukan paremmin näytteen savipitoisuuden kanssa kuin MB-menetelmällä saadut, kun taas MB-menetelmän CEC-arvot ovat jonkin verran paremmassa vuorosuhteessa näytteen humuspitoisuuden kanssa.

Vaihtuvien kationien, $\mathrm{Mg}, \mathrm{K}$ ja $\mathrm{Na}$, \%-osuudet kaikista vaihtuvista kationeista vähenevät näytteiden savipitoisuuden laskiessa, kun taas Ca-kationin osuus tällöin kasvaa lievästi. Mg-kationilla mainittu suuntaus on voimakkain.

Vaihtuneitten Ca- ja Mg-kationien suhde on riippuvainen $(\mathrm{r}=0.56 * * *)$ näytteen savipitoisuudesta siten, että suhdeluku $\mathrm{Ca} / \mathrm{Mg}$ on sitä suurempi, mitä vähemmän savea maa sisältää (taul. $1, \mathrm{q})$. 